\title{
The hygienic transition from cesspools to sewer systems (1840-1930): The dynamics of regime transformation
}

\author{
Frank W. Geels* \\ Eindhoven University of Technology, IPO 2.10, PO Box 513, 5600 MB Eindhoven, The Netherlands \\ Received 6 October 2004; received in revised form 6 April 2005; accepted 6 June 2006 \\ Available online 21 July 2006
}

\begin{abstract}
This article addresses the topic of transition and system change, and proposes endogenous regime transformation as alternative transition path to technological substitution. Using sociological and institutional insights, the dynamics of regime transformation are conceptualised. Two characteristics are pressure from outsider groups and adjustments in cognitions, norms and formal rules, enacted by regime insiders. The transformation perspective is illustrated with a historical case study, the hygienic transition from cesspools to integrated sewer systems in The Netherlands. The case study is used to make additions to the transformation perspective, particularly with regard to tactical and strategic games.
\end{abstract}

(C) 2006 Elsevier B.V. All rights reserved.

Keywords: Hygienic transition; Sewer systems; Regime transformation

\section{Introduction}

This article addresses the systems level in Freeman and Perez's (1988) innovation typology. They distinguish: (a) incremental innovations; (b) radical innovations at the product level (technological discontinuities); (c) changes of the technology system, which are farreaching changes at the level of sectors and societal functions (e.g. transport systems, energy systems); (d) changes in the techno-economic paradigm (TEP) which affect the entire economy (e.g. steam, ICT). Changes in TEP are studied in long-wave theories, and radical innovations receive much attention in business studies. But transitions at the systems level are somewhat underaddressed and taken up in this article.

\footnotetext{
* Tel.: +31 40247 5414; fax: +31 402444602.

E-mail address: f.w.geels@tm.tue.nl.
}

The particular case study is the transition from cesspools to sewer systems in The Netherlands. This system change was part of the wider epidemiological transition and decreasing death rates (Fig. 1).

Much of decreasing death rates (50-70\%) was due to a decrease in infectious diseases (e.g. tuberculosis, dysentery, cholera, typhoid) (Mackenbach, 1992). The hygienic transition to sewer systems was crucial in this respect. The empirical question is how this transition came about? The theoretical aim is to expand the understanding of transition dynamics.

Much of the literature on transitions and system innovation emphasises technological substitution as core process, for instance, several contributions to the multilevel perspective (Rip and Kemp, 1998; Kemp et al., 1998; Elzen et al., 2004; Geels, 2005a,b). This perspective argues that new technologies first emerge in particular market or technological niches, where they are nurtured and developed. These niche-innovations break through in mainstream markets and replace exist- 


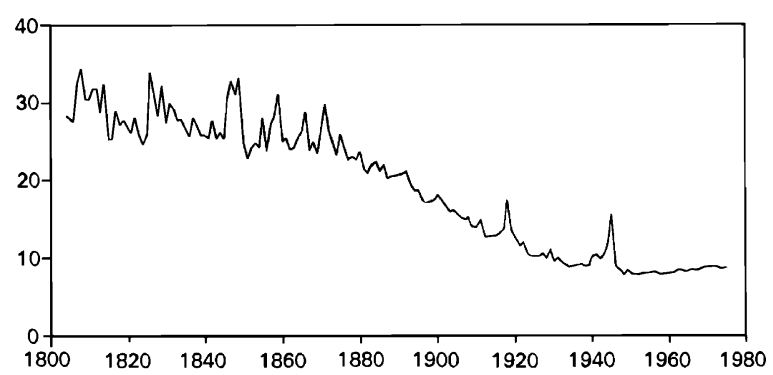

Fig. 1. Death rates in The Netherlands (number of deaths per 1000 person per year) (Mackenbach, 1992: 10).

ing systems, when several processes link up: (a) stabilisation of the niche-innovation in a dominant design, increasing support from powerful actors, and improving price/performance characteristics; (b) external environmental changes, which create pressure; (c) weakening of the existing regime (increasing problems, loss of faith). Case studies have demonstrated that such niche-driven substitution paths exist, e.g. the transition from sailing ships to steamships (Geels, 2002), the transition from manual unloading of grain ships to mechanical unloaders (Van Driel and Schot, 2005).

But niche-driven substitution is not the only possible transition path (see also Smith et al., 2005). ${ }^{1}$ This article proposes regime transformation as alternative transition path. One difference is the role of incumbent regime actors. On the niche-driven substitution path, incumbents form barriers and stick to the old regime. Hence, newcomers and fringe actors are important drivers for the transition, who eventually drive incumbents off the markets. On the transformation path, however, incumbents do not disappear. Instead, they enact the transition path and alter the course of development trajectories as they gradually change their perceptions, goals, identities, knowledge and practices. The second difference relates to regime stability. On the niche-driven substitution path, existing regimes are relatively stable, while niche-innovations appear and are nurtured 'below the surface'. The breakthrough of these novelties in mainstream markets triggers disruptions and (relatively) rapid regime change. On the transformation path, however, regimes change more gradually and over a longer period of time, in response to outside pressures (see below). These pressures lead to adjustments in regulative, normative and cognitive aspects of regimes (see below). If new technologies play a role in the transformation path,

\footnotetext{
${ }^{1}$ Elsewhere Geels and Schot (submitted for publication) react more systematically to the transition typology proposed by Smith et al. (2005).
}

these follow such regime adjustments, rather than drive them, as in the substitution path.

Section 2 describes the basic sociological mechanisms of regime transformation. Section 3 empirically demonstrates these mechanisms with an historical case study. The 'naming' of this case study, the transition from cesspools to sewers, suggests a technology-driven substitution process. But the case study will show that the large-scale shift to sewer systems was preceded by many regulative, normative and cognitive changes in the regime. Section 4 analyses the case study and suggests additions to the transformation perspective. The article ends with conclusions in Section 5.

\section{The dynamics of regime transformation}

The regime concept is situated at the level of organizational fields, coordinating the behaviour of actors that are part communities. Nelson and Winter (1982) coined the term 'technological regimes', referring to the cognitive routines that are shared in a community of engineers and guide their R\&D activities. Technological regimes create relative stability at the sectoral level and lead to incremental innovation along technical trajectories. Sociologists of technology broadened the focus, arguing that scientists, policy makers, users, and special-interest groups also contribute to patterning technological development (Bijker, 1995; Williams and Edge, 1996). Hence, Geels (2004) proposed broader socio-technical regimes to understand the coordination of multiple social groups involved in the production, distribution, use and regulation of technologies. For instance, the waste-disposal regime of the mid-19th century consisted of several related social groups. Rich people had private cesspools, which were emptied several times per year by private waste collection companies. The latter processed the excrements, selling them as fertilizer to farmers. Poor people dumped excrements on streets or in canals. City governments made ordinances against this practice, but with little effect. To ensure sufficient flushing, Departments of Public Works dredged canals and installed public privies. The national government was not a regime actor, because political responsibilities for waste and public health were decentralised.

The content of regimes has been conceptualised in two ways. The sectoral system of innovation approach defines technological regimes with intrinsic knowledgerelated properties. Malerba and Orsenigo (1997), for instance, distinguish three characteristics of technical regimes: (a) opportunity and appropriability conditions; (b) degree of cumulativeness of technological knowledge; (c) characterization of the relevant knowledge 
Table 1

Three dimensions at institutional field level (Scott, 1995: 35)

\begin{tabular}{llll}
\hline & Regulative & Normative & Cognitive \\
\hline Examples & $\begin{array}{l}\text { Laws, regulations, standards, } \\
\text { procedures, incentive structures, } \\
\text { governance systems }\end{array}$ & $\begin{array}{l}\text { Values, norms, role expectations, } \\
\text { duty, codes of conduct, } \\
\text { behavioural practice, identity } \\
\text { Basis of compliance }\end{array}$ & $\begin{array}{l}\text { Belief systems, models of reality, bodies } \\
\text { of knowledge, guiding principles, search } \\
\text { heuristics }\end{array}$ \\
Mechanisms & Coercive (force, punishments) & $\begin{array}{l}\text { Social obligation } \\
\text { Normative pressure (social } \\
\text { sanctions such as 'shaming') }\end{array}$ & Mimetic, learning, imitation \\
Basis of legitimacy & Legally sanctioned & Morally governed & Culturally supported, conceptually \\
& & & correct \\
\hline
\end{tabular}

base. This conceptualisation works well to understand the innovative performance of sectors and the dynamics of industry structures. But the content of technological change remains a black box. This article uses a more sociological regime definition, which looks at the content of shared cognitive rules in a community (problem agendas, search heuristics, guiding principles). Nelson and Winter (1982) have such a definition, and so do Rip and Kemp (1998: 340), who define a technological regime as: "the rule-set or grammar embedded in a complex of engineering practices, production process technologies, product characteristics, skills and procedures, ways of handling relevant artefacts and persons, ways of defining problems; all of them embedded in institutions and infrastructures." Building on neo-institutional theory, Geels (2004) distinguished three dimensions of socio-technical regimes: regulative, normative, and cognitive (Table 1).

These three dimensions contribute to the stability of socio-technical regimes. Cognitive routines may blind engineers to developments outside their focus (Nelson and Winter, 1982), so that core competencies turn into core rigidities (Leonard-Barton, 1992). As long as actors expect and believe that problems can be solved within the existing regime, they will continue along existing paths and not explore radical innovations. Normative dimensions have stabilising effects, when people adapt their behaviour and lifestyles to technical systems. Furthermore, social networks are stabilised by mutual role perceptions, expectations of proper behaviour, identities and 'sense of self'. Regulative dimensions may stabilise the regime through legally binding contracts, standards, or government subsidies that favour existing technologies (Walker, 2000). As a result of these mechanisms, existing socio-technical regimes are characterised by stability and lock-in. Regime actors resist radical change, and dedicate activities towards incremental improvement along existing trajectories.
So, given these stabilising mechanisms, how do sociotechnical regimes change? One answer is provided by the multi-level perspective, which argues that radical novelties emerge in niches (Rip and Kemp, 1998; Van Driel and Schot, 2005; Geels, 2005a,b). The novelties are further improved in these niches, while regime actors are blind to these developments. When external landscape developments create problems in the regime, the improved niche-innovations may break through, substitute the old technology, and establish a new regime.

But technology-push substitution is not the only transition pathway. Transitions can also occur through gradual regime transformation. The core of this process is the gradual change in behavioural norms, formal regulations and cognitive belief systems, shared in a particular community. These changes alter the direction of search, investment and innovation activities, thus reorienting development trajectories. Van de Poel $(2000,2003)$ argues that regimes only transform substantially if there is pressure from outsiders, i.e. actors that are excluded from the regime community. When regimes create negative outcomes (e.g. market failures, negative externalities), outsiders may organise themselves and engage in activities to influence regime insiders (Fig. 2).

Van de Poel (2000) distinguishes three outsider groups with different action repertoires. First, societal pressure groups voice protest, demanding solutions for what they perceive as negative outcomes. The hope is that regime insiders will respond to this pressure by changing their problem agendas and practices, and reorienting development and innovation trajectories. Outside

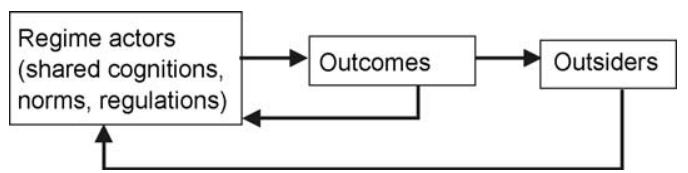

Fig. 2. Sociological dynamics of regime transformation (based on Van de Poel, 2000: 388). 
pressure groups may try to mobilise public opinion and create normative credibility pressure on regime insiders. Societal pressure groups can also lobby policy makers for tougher regulations that would push regime developments in certain directions.

The second group are outside professional scientists or engineers. They may possess specialist knowledge that allows them to criticise technical details of regimes. If regime insiders accept this criticism and place the problems on their agenda, this creates windows of opportunity for outside specialists to influence cognitive regime dimensions more directly. Regime actors may allow outside specialists to acquire roles as (partial) insiders, something that enables the import of new knowledge, design concepts, and search heuristics. These cognitive regime changes may reorient innovation trajectories and eventually lead to substantial changes.

The third group are outsider firms and entrepreneurs who develop technical alternatives and radical novelties that compete with the existing technology. The demonstration that alternatives are possible may change perceptions of regime insiders, who subsequently reorient their innovation activities. Table 2 summarises the different mechanisms.

These mechanisms form the basis of a sociological regime transformation perspective, organised around insider-outsider interaction. But the perspective is schematic, based on 'carrot and stick arguments' (voice protest, develop alternative knowledge and artefacts). More needs to be done to understand how regime transformation is enacted. Fig. 2 too easily assumes that protests from outsiders have immediate influence. But regime actors are unlikely to change their cognitions, behavioural norms and regulations at the first occurrence of outsider reactions. Instead, it probably takes prolonged conflicts, contestations and power struggles for outsiders to influence regime actors. The hypothesis is that regime insiders use tactics to defend themselves against outside interference, and that outsider groups strategically manoeuvre to get their concerns on the agenda. This hypothesis will be elaborated with a case study. The analysis in Section 4 then fleshes out the transformation perspective, addressing the following question: which strategies and tactics were used and how did their interactions eventually result in substantial regime changes in belief systems, behavioural norms and regulations?

\section{The Dutch hygienic transition from cesspools to sewer systems (1840-1930)}

The case study aims to illustrate the regime transformation perspective and further explore enactment strategies in insider-outsider interaction. It does not aim to unveil new historical facts. Hence, the case study is based on secondary sources from Dutch history of technology, social history and economic history. Much has been written in the international literature on hygienic transitions in other countries, e.g. America (Cain, 1978; Tarr, 1979,1988; Tarr et al., 1984; Melosi, 2000), United Kingdom(Wohl, 1983; Hamlin, 1992), Germany (Evans, 1987; Brown, 1988), and France (Reid, 1991). From an international perspective, Dutch cities were slow and relatively late in the hygienic transition to sewer systems (The Hague in 1893, Amsterdam in 1913). Many other European cities shifted earlier, e.g. Hamburg (1843), Berlin (1873), Breslau (1875), Karlsruhe (1877), Munich (1880). After the 'Great Stink' in 1858, London began work on the 'Main Drainage' in 1859, finishing the sewer system in 1865. Paris finished its underground sewer system in 1871. In the United States the first integrated sewer systems were built in Brooklyn (1855), Chicago (1856), and Jersey City (1859) (Tarr, 1988). The relative Dutch delay will be explained by analysing interactions between regime insiders and outsiders, situated in broader contextual developments.

The case study consists of three sub-sections, based on differences in insider-outsider interaction. In the first

Table 2

Mechanisms for outsider influence on regimes (adapted from Van de Poel, 2000: 391)

\begin{tabular}{llll}
\hline & Societal pressure groups & Outside specialists and engineers & Outside entrepreneurs and firms \\
\hline Resources & $\begin{array}{l}\text { Possibility to mobilise public } \\
\text { opinion, policy makers, and others }\end{array}$ & Specialist knowledge & Financial and managerial resources \\
Actions & Problem articulation & Develop alternative insights & Develop competing alternatives \\
Influence on regime & $\bullet$ Articulate problem (cognitive) & $\bullet$ Criticise technical details and & $\bullet$ Economic threat \\
& $\bullet$ problem articulation (cognitive) & $\bullet$ Demonstrate alternatives (cognitive) \\
& $\bullet$ Lobby for stricter regulations & $\begin{array}{l}\bullet \text { Develop alternative knowledge } \\
\end{array}$ & is made available)
\end{tabular}


period (1840-1870) outsiders struggled to understand the relationship between hygiene and infectious disease, and get the problem on the agenda. In the second period (1870-1890), outsiders build pressure for reform. Regime insiders responded with step-wise changes in perceptions, regulations and behavioural practice. In the third period (1890-1930), reform pressure further increased because of alignments with broader contextual developments, leading to changes in identity, role perceptions and investment patterns by regime insiders. This culminated in the implementation of integrated sewer systems.

\subsection{Getting hygienic problems on the agenda (1840-1870)}

\subsubsection{The regime of waste disposal}

For most of the 19th century, urine, faeces and other domestic wastes were the largest urban waste streams (Van Zon, 1986). Middle and upper class families had in-house privies, where excrements fell down a tube into privy vaults. Cesspools and privy vaults were cleaned by private contractors. They dumped the waste or sold it as fertilizer to farmers. Other urban residents had no inhouse sanitary facilities. They deposited waste on streets and in surface waters, which removed it from sight. Human wastes were also disposed in cesspools in small backyards, which were emptied a few times a year. Residents tried to avoid this dirty work by creating drains or pipes that allowed cesspools to spill their contents in canals or gutters.

Rainwater drainage occurred through gutters, ditches and canals. People also dumped garbage and waste in street gutters. To reduce stench and facilitate crossing by pedestrians, gutters were sometimes covered with wooden boards, creating the first underground sewers. These early drainage sewers were constructed haphazardly and had flat-bottom, rectangular shapes. This facilitated deposition of solid wastes near the corners, leading to clogging problems (Van den Akker, 1952).

The Municipal Law (1851) gave local city authorities high autonomy vis-à-vis the national state, making them responsible for public works, public health, hygiene, and social order. The government decreased its involvement in public life, cutting state expenditures as percentage of GNP from 14\% in 1840 to $8 \%$ in 1870 (Kossman, 1976). Following the new constitution in 1848, $10.7 \%$ of Dutch men above 23 years could vote for Parliament and 18\% for local city councils (Verdoorn, 1965). Representation of city councils was in the hands of shopkeepers, manufacturers, merchants, builders, lawyers and estate agents.
These council representatives were advocates of 'economy' and low taxes. Hence, city governments limited their involvement in public life, backed up by liberal political ideology. Public investments in waste-disposal facilities were low. The main task of Public Works Departments was dredging the canals to ensure sufficient water flow and removing depositions from gutters when these were blocked (Van Zon, 1986). City authorities issued regulations against public waste dumping, but these were ineffective, because of limited policing (Houwaart, 1993b).

A problem in the waste-disposal regime was that heaps of waste accumulated in streets and canals. When waste was not flushed away, it decayed and created stench (Van Zon, 1986). Filth and stench were normal nuisances to be tolerated. But there was also concern, because medical opinion saw bad smells, in particular miasmas emerging from decaying organic matter, as causes of diseases. But no action was taken, because health was seen as an individual responsibility. The shared conviction was that people had to take care of themselves (Houwaart, 1993b).

A major shock came from a new disease, cholera, which struck The Netherlands in major epidemics in 1832 and 1848. Doctors did not understand the cause and diffusion of cholera, which sprang up simultaneously at multiple places, without direct contact between people (Houwaart, 1993a). This stimulated the belief that environmental factors were important, especially miasmas. In Britain the shock of cholera provided the impetus for discussions about public hygiene, culminating in the Public Health Act (1848). In The Netherlands, however, public authorities fell back into complacency once the epidemics passed (Houwaart, 1991).

\subsubsection{Criticism from outsiders: the hygienist doctors}

Building on insights from the 'sanitarian movement' in France and England (Houwaart, 1991), Dutch 'hygienist doctors' developed medical statistics as a research method to analyse infectious diseases. In the 1840s and 1850 s they mapped the distribution of diseases and death rates over different cities and neighbourhoods, correlating the differences with hygienic variables, such as waste heaps, insufficient street cleaning, canals with still water and decaying organic material (Houwaart, 1993a). The resulting 'death maps' were powerful images. The hygienist doctors published their results in journals, reports and newspapers, warning that existing wastedisposal practices contributed to the spread of infectious diseases. Hygienist doctors also suggested improvements, e.g. clean drinking water, removal of waste, clean 
air and sunlight. But public authorities did not implement these suggestions.

The hygienist's statistical correlations did not address the causal mechanisms in the spread of infectious diseases. Data collected during the second cholera epidemic (1848) suggested that areas with similar environmental conditions were affected differently, suggesting at least some transmission between people. In response, a hybrid miasma-contagion theory was developed arguing that the origin of cholera laid in environmental conditions (miasmas) and that transmission occurred from person to person (Houwaart, 1991). John Snow, a British hygienist, proposed another theory in 1854, arguing that cholera was spread through drinking water contaminated with faeces from cholera patients. But Dutch doctors showed little interest in this theory and paid more attention to refinements of the hybrid miasma-contagion theory (Houwaart, 1991). Nevertheless, the discussions in the Dutch medical community led to more attention to linkages between cholera and sanitary conditions. Although causal mechanisms were uncertain, the medical community suggested that local authorities should reduce waste-accumulation. Also citizens created pressure, writing letters to city councils and newspapers to complain about stench and waste problems.

\subsubsection{Limited responses from regime actors}

In response to these pressures, city governments publicly expressed concerns. But they did not implement new waste-removal practices or sewers systems. City governments argued that such systems were expensive and that too many uncertainties existed in the knowledge about causal relationships between waste and disease (Van Zon, 1993). But city governments could not afford to do nothing. Hence, they implemented incremental changes. The main effort was to improve water circulation to flush away waste (Van Zon, 1986). Canals were dredged more frequently to maintain sufficient depth, and steam engines were used to pump in more fresh water. Some cities filled up those canals that stank worst (Buiter, 2005). In those instances, sewer pipes were implemented to provide rainwater drainage.

Rotterdam's city council accepted a plan in 1854 to create a canal-flush waste-removal system. Using the tide, water from the river Meusse would flush the canals twice a day. Legal and technical issues delayed construction, but in 1865 the new system was opened. In this system, canals functioned as open sewers, which were frequently flushed (Van den Noort, 1990).

While Dutch cities were slow to introduce underground sewer systems, cities abroad made more headway, e.g. London (1865), Paris (1871), Berlin (1873),
Breslau (1875). These sewer projects provided space for learning processes about design aspects, e.g. sewer slopes, flow speeds, maximum and minimum diameters, drainage-basin size, rainfall patterns (Van den Akker, 1952). A contested issue was the choice between combined or separate sewers (Tarr, 1979). Combined sewers collected all waste together (rainwater, household wastewater, excrements). Sewer pipes should be wide enough to deal with heavy rains. But in periods of little rain, such sewers might become silted up, leading to sedimentation, decaying organic material and sewer gases. It also meant that faeces were lost as possible fertilizer. In separate sewer systems, rainwater and domestic wastewater (including urine and faeces) were collected separately. Faeces could be processed and sold as fertilizer to farmers, something that hygienists preferred. But the separate system was more complex and more expensive. It was not clear which system was better. Most sewer projects in the 1850s and 1860s were combined sewer systems, because they were simpler and cheaper. But the choice remained contested. Especially American cities built substantial numbers of separate systems in the 1880s and 1890s (Tarr, 1979,1988).

There was also contestation about the shape of sewer pipes and material choice (Hamlin, 1992). Traditionally, sewers were constructed of cut stone and brick. But these materials had rough surfaces that limited flow and throughput. Hence, Chadwick advocated small earthenware pipes with high-pressure, rapid flows, thus preventing the formation of sewer gas. Others warned that the pipes might break if clogging occurred. In the early 1850s Chadwick's ideas were tried in parts of London. But within weeks there were breakages (Hamlin, 1992). Hence, small-diameter pipes were restricted to connect houses to main sewers. For trunk lines and intercepting sewers, bricks and stones were used.

Dutch city governments and engineers were aware of foreign sewer projects. In the 1850s and 1860s many urban commissions investigated the options, producing many reports for city councils. But none of the plans and proposals were implemented, because of high costs. There were also technical doubts, because the wet, unstable Dutch soil could easily subside, leading to fractures in sewer pipes (Daru and Van Zon, 1987). Furthermore the flatness of the country meant that many cities had insufficient slope for gravity-based flow. Hence, pumps should be added to sewer systems, increasing costs (Van Zon, 1993).

In response to the relative inaction at the local level, the Minster of the Interior issued national Medical and Health Laws in 1865. These laws called for the creation of local health inspectors to investigate local health con- 
ditions. But these local inspectors had few formal powers and could only advise city governments. These advices were often ignored. In fact, city governments obstructed local health inspectors, paying low wages, giving them too many responsibilities for large neighborhoods, and denying them resources to hire extra people (Van Zon, 1986). Local health inspectors complained about these issues, but neither Parliament nor the Minister supported them. Nevertheless, the presence of inspectors formed a mechanism through which hygienic knowledge entered the waste-disposal regime. The inspectors acted as 'hygienic conscience', continuously placing the need for hygienic reform on the agenda of local authorities.

\subsection{Building pressure for reform and step-wise regime changes (1870-1890)}

\subsubsection{Increased pressure from outsiders}

In the 1870 s and 1880s, pressures on the wastedisposal regime increased. One reason was that waste problems grew worse, because urban populations increased rapidly as industrialization gathered speed (Kossman, 1976). Because working class families lived without sanitary facilities, waste disposal on streets, in canals and public cesspools increased (Fig. 3).

Secondly, pressure from the medical community increased. Debates about infectious diseases increasingly saw polluted drinking water as important variable. Following the cholera epidemic of 1866/7, a National Drinking Water Commission (1868) was created. The commission confirmed correlations between faeces, polluted drinking water and cholera. The commission's report received much publicity, and there were demands on public authorities to be more active regarding drinking water and waste disposal. But neither nationally nor locally did much action follow (Van Zon, 1986).
Meanwhile, a new micro-organism theory emerged in the medical community. Pasteur developed the first ideas between 1860 and 1865, but many doctors reacted sceptically, because micro-organisms were too small to see. By 1880, however, Cohn and Koch developed colouring methods that visualised the existence of bacteria. The new theory could explain the statistical correlations between filth, bad hygiene and infectious diseases. This changed the perception of waste-problems and created more pressure on regime actors (Houwaart, 1991). In public opinion, the micro-organism theory provided a model with rhetorical power: armies of microbes waiting to invade the body (Mokyr and Stein, 1997). Washing and scrubbing were propagated as defence mechanisms, emphasising the importance of cleanliness (Meulders, 1992).

The third reason for increased pressure was that hygienist doctors and civil engineers formed a sanitary reform coalition. Hygienists articulated problems and general solutions, while engineers developed specific technical designs. Together with discussions in public opinion and newspapers this gave rise to a hygiene movement, which increased pressure on city governments.

Fourth, hygienist doctors and engineers enhanced their societal prestige. Engineers were widely respected because of their involvement in rail networks, bridges, canals, and gasworks. Specialisation and professionalisation led to the creation of sanitary engineers, who claimed to speak with authority on sanitary issues (Tarr et al., 1984). Engineers also acquired roles inside the waste-disposal regime through their influx in Departments of Public Works (Buiter, 2005). The hygienists boosted their prestige through alignment with the professional Society for the Advancement of Medical Science (NMG) (Houwaart, 1993b). In the 1870s the NMG became increasingly involved in public health issues, and

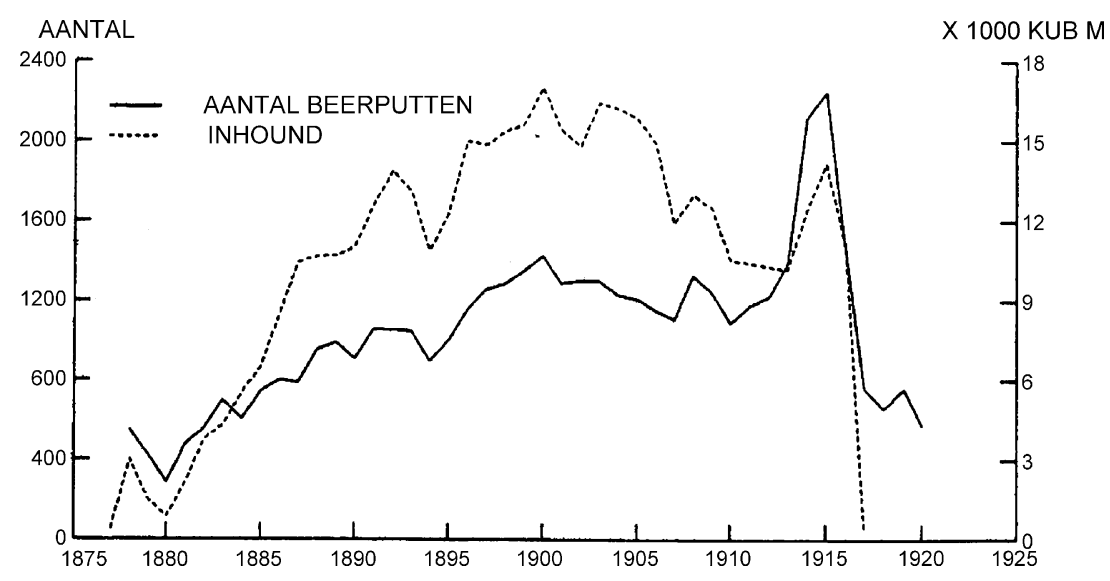

Fig. 3. Number of cesspools (filled line, left axis) and volume emptied in $1000 \mathrm{~m}^{3}$ (dotted line, right axis) in Amsterdam (Van Zon, 1986: 78). 


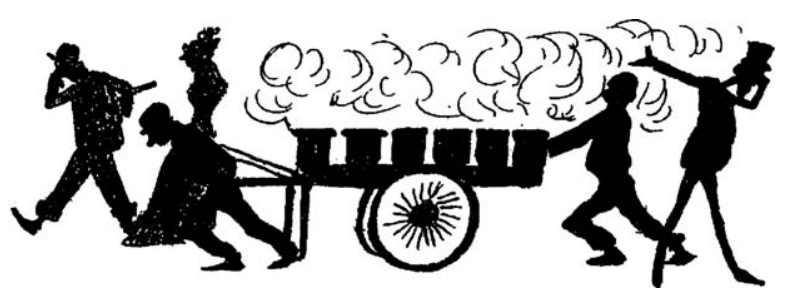

Fig. 4. Cartoon from 1892 about the barrel-collection system (Houwaart, 1993b: 83).

new journals for public health debates were created. ${ }^{2}$ These developments enhanced the strength of criticisms from hygienist doctors and engineers.

A fifth reason for increased pressure was issue linkage. Waste, hygiene and public health problems were increasingly linked to the social issue. Poverty, socioeconomic inequality and class struggles were high on the political agenda, because of strikes and marches by labour unions. Waste and hygiene problems became more pressing, as they linked with the social issue.

\subsubsection{Responses from regime insiders: experimentation with dry-collection methods}

In response to increased pressures, city governments mainly relied on traditional solutions such as improved water circulation (dredging, pumps). But they also diversified and explored new directions. This created space for two systems for the removal of human excrements: the barrel-system and the pneumatic Liernur-system.

In the first system, people deposited their excrements in barrels or pails, which were collected several times a week (Van Zon, 1986). Barrels were transported to a central collection place, where their contents were processed into compost, and then sold as fertilizer. One nuisance was that households had to keep barrels in-house until collection. Another nuisance was that barrel transport was accompanied by smells and leakages (Fig. 4). Engineers opposed barrel-collection, because of imprecision and leakages. But hygienists and agricultural experts praised the system, because excrements fulfilled a useful function as fertilizer.

Because the city of Groningen earned money from fertilizer sales, other cities also became interested. In Leeuwarden the number of households with barrels increased from 300 to 2500 between 1873 and 1879 . In Dordrecht the number increased from 314 in 1874 to 2759 in 1883 . Other cities also implemented the barrel-

\footnotetext{
${ }^{2}$ Schat der Gezondheid ('Treasure of Health'), Tijdschrift voor Gezondheidsleer ('Journal for Health Studies'), Hygieia ('Hygiene') en De Gezondheid ('Health') (Van Zon, 1986).
}

system, e.g. Rotterdam, Amsterdam, Vlaardingen, Leiden, Arnhem, Maastricht, Nijmegen (Van Zon, 1986). The system was not always profitable, because prices of human excrements varied between locations, depending on soil conditions, farmers' needs and availability of other types of fertilizer (Daru, 1985).

The entrepreneurial engineer Liernur developed and promoted a pneumatic system, which consisted of toilets, funnels, and underground connecting pipes that ended in a collection reservoir. Excrements were collected daily in the reservoir, using a steam pump to create a vacuum. Faeces were processed and sold as fertilizer. Technical feasibility was demonstrated in a small-scale project in Breda in 1867. Hygienists favoured this system because of its high cleanliness. There was no spilling, and no labourers carrying dirty barrels. But the system was complex and expensive. City governments feared that high construction costs would not be recovered from excrement sales. Leiden sponsored a demonstration project in 1871 , involving 1200 people. The project was technically successful, but costs were higher than expected (Van Zon, 1993). In 1872 Amsterdam also set up a demonstration project, involving 1700 people. The experiment was successful, although the quality of excrement (mainly its nitrogen content) was lower than expected. Nevertheless, Amsterdam's city council decided to expand the Liernur-system in 1879 (Buiter, 2005). The mixed experiences in Leiden and Amsterdam and the high complexity and costs, made other cities hesitant about the Liernur-system.

In this period, there was much variety, with different cities exploring different waste-disposal systems. Variety also existed within cities, for instance, in Amsterdam and Rotterdam (Van den Noort, 1990). Cities tried to learn from each other's experiences. This was difficult, however, because local factors influenced technical and economic viability of different systems. If cities were close to large rivers, this provided the possibility of using large amounts of water for flushing. The vicinity of farmers and low transport costs stimulated the economic viability of excrement sales. And in regions with peat and sandy soils, farmers had higher fertilizer needs than in clay regions (Daru, 1985). Uncertainty was further enhanced by engineers, hygienists, and agricultural experts voicing different opinions about the different systems. Given these uncertainties, cities mostly opted for the cheapest option, the barrel-system.

There were also discussions, committees and reports about sewer systems. Engineers favoured sewer systems because they formed an encompassing solution to waste problems. Some engineers developed calculations that showed that lower mortality and financial gains would 
Table 3

Rejected plans for sewer systems (Daru and Van Zon, 1987)

\begin{tabular}{lll}
\hline Year & City & Engineer \\
\hline 1858 & Rotterdam & Scholten \\
1863 & Arnhem & Van Gendt \\
1870 & Amsterdam & Van Niftrik \\
1870 & Tilburg & Havelaar \\
1872 & The Hague & Van der Waayen Pieterszen \\
1872 & Arnhem & Henket \\
1876,1878 & The Hague & Reinders \\
1897 & Amsterdam & Lambrechtsen van Ritthem \\
1902 & Amsterdam & Van Hasselt \\
\hline
\end{tabular}

outweigh expenditures. Sewer systems would also save money that was spent on the cleaning of cesspools and privy vaults (Tarr et al., 1984). A third argument was that cities with improved sanitary conditions would attract more population and industry. Inspired by sewer systems abroad, Dutch engineers and civil servants made many plans for integrated sewer systems, none of which was implemented (Table 3).

City governments felt that sewer systems were too costly, conflicting with their principle to keep taxes low (Daru and Van Zon, 1987). Hence, they preferred cheaper waste collection options such as the barrel-system. Furthermore the emergence of piped water systems in the 1870s and 1880s absorbed much political attention and city finances (Geels, 2005b). It was hoped that hygiene problems would become less pressing if people drank clean, piped water. But piped water systems had an unexpected side effect. Extra water entered households, but there were no pipes and mains for proper removal. The extra water was released in cesspools, which overflowed and released their contents in surface waters. Furthermore, piped water stimulated the adoption of water closets. But, in the absence of sewer systems, these water closets flushed their contents into cesspools, privy vaults and canals, creating additional pollution of surface waters (see Melosi, 2000 for similar patterns in America).

\subsection{The gradual shift to sewer systems (1890-1930)}

\subsubsection{Continued outside pressure and shifts in public opinion}

The barrel-collection system was not an encompassing solution to waste problems. As urbanisation continued in the 1890 s, waste-problems exacerbated, also because of the diffusion of piped water and water closets. Protests from the hygienic movement, sanitarians and engineers gained force. But most pressure came from cultural changes and public opinion. An ideology of cleanliness emerged, and exterior cleanliness came to represent virtuousness, respectability and civilisation (Meulders, 1992). New medical theories also emphasised cleanliness. To combat microbes, people had to wash, scrub and use soap. The ideology of cleanliness led to a value change: urbanites no longer saw filth as a nuisance to be tolerated, but as a hazard to their health (Tarr et al., 1984). Public opinion increasingly perceived waste and stench as unacceptable. Another change in public opinion was increased sensitivity about the social issue. Novels, newspaper reports, protests by socialists and labour unions forced this issue on the agenda. Parliamentary Inquiries stimulated political awareness of the living conditions of the proletariat, including problems of waste, filth, and disease (Verdoorn, 1965). A third cultural change was the emergence of a new civic spirit, the increase of philanthropical, middle class reform organisations. Calls for more active public authorities led to a change in the role perception of public authorities. The new view was that city governments had a public responsibility to improve living conditions for all residents (Verdoorn, 1965). All these developments resulted in a widespread feeling that hygienic conditions had to be improved.

\subsubsection{Changes in the waste-disposal regime and the shift to sewer systems}

Also within the regime, there was pressure for change. Departments of Public Works became powerful spokespersons for change, something that was related to the influx of engineers, who imported new knowledge and competences. Furthermore, democratisation processes changed the political rules of the game. In 1887 the right to vote was widened, allowing $28.6 \%$ of the male population to vote in Parliamentary elections (Verdoorn, 1965). In 1896 the attributive right to vote was installed. And in 1917 the general right to vote was extended to all men, and in 1919 to all women. This democratisation formed an incentive for politicians to pay more attention to working classes (also Brown, 1988). Formal rule changes thus altered the cognitive guiding principles on the political agenda: improving general living conditions became more important, while keeping taxes low became less important. Because of these regime internal and external developments city governments became more interested in encompassing waste-disposal solutions. This was also financially possible, because rapid economic growth between 1890 and 1914 led to higher tax incomes (Kossman, 1976).

Furthermore, costs and benefits of different wastedisposal systems were influenced by developments in other regimes. The agricultural regime saw the emer- 
gence of artificial fertilizer in the 1890s, diminishing farmers' demand for human excrements. This negatively affected the viability of the Liernur-system and barrelsystem. The water supply regime saw the diffusion of piped water and water closets, resulting in human waste streams with higher water content. This reduced fertilizer values and economic feasibility of the Liernur- and barrel-system. Expansion in the housing regime resulted in new neighbourhoods, where sewer pipes could be implemented before houses were build (Daru, 1985).

In this context, the Liernur-system gradually disappeared, barrel-collection was gradually phased out, and the option of sewer systems seemed more attractive. But even with these favourable circumstances, the decision to implement sewers still depended on local circumstances and contestations.

In the 1880s The Hague's city council discussed plans to construct a canal-flush open-sewer system. This plan involved the building of two new canals: one to divert water from The Meusse to The Hague and one to carry off waste to the sea. The city of Schevingen, a seaside tourist resort, opposed this plan, fearing pollution of its beaches. After long negotiations, agreements were reached about canal location and times for opening the sluices. Implementation of the plan started in 1888 (Van den Noort, 1990). But the new system did not function well. Because water supply was limited, solid wastes often floated in the canals. This was increasingly experienced as a stain on the reputation of the royal residence. Hence, in 1893 the city council accepted an integrated sewer plan. The plan also involved the filling up of canals in the city centre, to create more space for wagons, bicycles, and trams. Barge owners, shippers and traders protested, because canal elimination would limit the supply of goods and produce. To accommodate these protests, a new harbour was constructed (Buiter, 2005). The linkages between the sewer plan, canal fill plan and harbour plan formed a package deal that made the reform plan acceptable.

In Amsterdam, many plans for sewer systems had been discussed. The city engineer Van Niftrik made a design in 1870, but this was dismissed, because of high cost (Werkman, 1982). In 1879 different wastedisposal options were discussed. But the city council opted for an enlarged Liernur-system, not for sewers (Buiter, 2005). In the 1890s, the stinking canals were increasingly seen as a stain on Amsterdam's reputation as a modern city. In 1903, under public pressure, the city government commissioned the Director of Public Works to develop a sewer plan for new suburban neighbourhoods (Werkman, 1982). But the plan was postponed because of high costs. A new committee was installed, which recommended in 1906 to build a sewer system
(Buiter, 2005). The city council accepted the recommendations, but debated until 1911 over specific sewer designs. In 1913 Amsterdam finally opened an integrated sewer system for the suburbs. The city centre had to wait until the late 1930s (Buiter, 2005).

In smaller cities the transition to sewer systems was slower, because financial means were lacking and because pollution was more easily diluted. In 1938 all cities with more than 50,000 inhabitants had sewer systems, although many of them also still had cesspools and barrel-collection systems (Van den Akker, 1952). But in many small cities, especially in the countryside, cesspools and barrel-collection systems remained in use until after World War II.

\section{Analysis}

Did the hygienic transition follow a regime transformation path or a niche-driven substitution path? Clearly there were aspects of substitution, with sewers replacing cesspools. Furthermore, new technologies initially emerged in technological niches, carried by subsidized experimental projects. Examples were projects with the Liernur-system, and early sewer systems in expanding neighborhoods of big cities. This is in line with the nicheinnovation literature, which argues that experimental projects facilitate learning processes and social network building (Kemp et al., 1998). But the hygienic transition was not a niche-driven substitution process. One reason is that sewer systems were not disruptive in the sense of new knowledge making old knowledge obsolete. Instead, existing knowledge about bricks, pipes, water flows and pumps remained relevant. Additional knowledge had to be developed about how different components were best combined, about costs and benefits of combined or separate sewers, the shape of sewer pipes, material choice, sewer slopes, flow speeds, and soil conditions. But this knowledge had an add-on character, and could be learned by incumbent actors. While Tushman and Anderson (1986) only distinguish between 'competence-enhancing' and 'competence-destroying' innovations, the shift to sewer systems points to a third category of 'competence-expanding' innovations. In this kind of innovations, incumbent regime actors adjust and reorient themselves by incorporating new knowledge. Second, the transition was not a radical substitution process, because in a technical sense sewer systems grew out of the canal system through a step-wise and gradual process. The first sewers consisted merely of underground gutters for rainwater drainage. Then, as stinking canals were filled up, more individual sewer pipes were implemented for drainage purposes. Subsequently, the 
individual sewer pipes were connected together in closed sewer systems. This process was more a gradual transformation than a radical substitution. A third argument is that the implementation of integrated sewer systems was preceded by many cognitive, normative and regulative changes in the regime. Although sewers emerged in technological niches, their implementation and broader diffusion depended on these gradual transformations of the existing regime.

The hygienic transition to sewers matches two conceptual characteristics of regime transformation: (a) regime insiders gradually change their cognitive beliefs, behavioral norms and formal regulations, which alter the course of development trajectories; (b) there was pressure from outsiders.

With regard to the first characteristic, it is clear that important cognitive changes occurred in the understanding of infectious disease (from miasmas to Pasteur's microbes), the public perception of faeces (from nuisance to valuable agriculture resource to dangerous substance that needs to be removed), views on health responsibilities (from individual to public responsibility). Important normative and behavioural changes occurred in the role perceptions of policy makers (from serving elites to sensitivity for the social issue and concern for the 'general interest'), political ideology (from minimal, liberal involvement in society to active interventionism), the morality of waste (from the normality of dirt to the ideology of cleanliness). Important regulative changes were the Public Health Act (1848), the Constitution (1848), the Municipal Law (1851), Medical and Health Laws (1865), and constitutional changes to widen the right to vote $(1887,1896,1917$, 1919).

With regard to the second characteristic, outsider groups clearly played a role in the hygienic transition. Protest initially came from outside specialists, in particular hygienist doctors, later joined by civil and sanitary engineers. On the one hand, these hygienists specialised and expanded their knowledge base about relationships between hygienic conditions and infectious disease. On the other hand, they stimulated the emergence of a hygiene movement to act as societal pressure group. To that end, hygienists published reports, gave lectures and tried to mobilise public opinion. In the 1870s and 1880 s this culminated in a broad hygiene movement. Newspapers, associations and societies, and members of city councils increasingly complained about bad hygienic conditions. The third group were outsider firms and entrepreneurs. Although Liernur was a good example, this group was less important in the case study, probably because of its public domain characteristic.
The different outside groups attempted to influence the existing waste-disposal regime. In these attempts, the mechanisms, specified in Table 2, can be discerned. The specialist hygienic doctors developed new knowledge about infectious diseases, and articulated medical statistics as powerful research method and tool. They criticised the details of waste-disposal methods, and suggested alternatives. Specialist engineers developed detailed technical sewer designs, although most of these were never implemented. Both specialist groups also acquired insider positions, allowing the influx of new knowledge into the regime: hygienist doctors filled the positions of local health inspectors that were created with the Health and Medical Laws (1865), and engineers increasingly took up positions within Departments of Public Works. The hygiene movement of the 1870 s and 1880 s was an important societal pressure group, demanding that regime actors pay attention to the hygiene problem. Their continued criticisms undermined the legitimacy of the existing regime, creating normative pressures on regime actors to work towards solutions. Hygienists also lobbied the government for stricter regulations, as follow-up of the Health and Medical Laws (1865). But this mechanism had little effect in the liberal and decentralised political culture. The role of outsider firms and entrepreneurs was limited. Liernur was an active entrepreneur, both commercially and in the media. His pneumatic system attracted much attention and stimulated debate. But it was not a major economic threat that pushed regime actors into further action.

Although most of the outsider mechanisms specified in Table 2 occurred in the hygienic transition, regime actors did not immediately change cognitions, norms and regulations in response to these outsider activities. Section 2 ended with the hypothesis that regime insiders defend themselves against outside interference, and that outsiders will strategically manoeuvre to get their concerns on the agenda. The case study makes it possible to flesh out insider-outsider interactions by identifying a range of tactics and strategies:

- Hide behind uncertainties. In the 1840 s and 1850 s regime actors showed little interest in criticisms from hygienic doctors, pointing to uncertainties in knowledge claims and causal disease mechanisms.

- Build credibility. To strengthen their arguments, hygienist doctors tried to enhance their credibility by publishing their findings in specialist journals. They also tried to gain acceptance within the professional Society for the Advancement of Medical Science (NMG). This took time, because the hygienists operated outside the mainstream medical-scientific 
paradigm. It was not until the 1870s that the NMG became more involved in public health debates.

- Develop powerful images. Medical statistics enabled hygienist reformers to develop powerful images (death maps) that articulated the hygienic problem. In the 1880s, Pasteur's micro-organism theory also provided a powerful image: armies of microbes invading the body. This image was used in public debates to stimulate the emerging cleanliness ideology and argue for better waste-disposal methods.

- Window dressing. In response to public debates, regime actors publicly expressed concerns about hygiene problems. But they were slow to translate this concern into substantial actions. They preferred to implement incremental improvements (enhanced water circulation, fill up stinking canals).

- Delegate to committees. Regime actors also used the tactic of installing committees to investigate problems and solutions. This allowed them to claim in public discussions that they were dealing with the issue. But recommendations of reports were seldom implemented, usually because of financial reasons.

- Incorporation and frustration. Regime actors incorporated and tried to neutralise critics. The position of local health inspectors, created after 1865, gave hygienist doctors an opportunity to enter the wastedisposal regime. But they were actively frustrated by city governments (advices were ignored, they received low pay, had too many responsibilities). On the other hand, the health inspectors continuously placed the need for hygienic reform on city council agenda's, acting as 'hygienic conscience'.

- Strategically use shocks. Health crises such as the cholera epidemics in 1832, 1848 and 1866/7 formed shocks to the regime. These shocks mobilised public opinion, creating windows of opportunity for reformers to strengthen their case for hygienic reform. But these shocks formed elements in the overall transformation process, not the main drivers.

- Coalition building and professionalisation. In the 1870s and 1880s, hygienist reformers strengthened their case by creating coalitions with civil and sanitary engineers. To enhance their prestige and authority both engineers and hygienist doctors used the tactic of creating professional societies or linking up with existing ones.

- Issue linkage. Outsiders used the tactic of 'issue linkage', linking their topic to broader societal debates and concerns. In the 1890s hygienic reformers framed hygiene problems as part of the broader social issue.

- Experimentation. As outside pressure continued, regime actors gradually moved from window dress- ing to experimentation with alternative options. On the one hand, experiments were a way to postpone major decisions. On the other hand, experiments facilitated learning processes and the accumulation of knowledge. Experimental projects also had spillover effects, with projects in one city triggering interest in others. This happened with barrel-collection, which was implemented on a broader scale after successes in Groningen.

- Shaming. In the 1890 s reformers in big cities such as Amsterdam and The Hague made comparisons to other cities abroad (benchmarking avant-la-lettre), arguing that stinking canals stained their reputation. City governments were sensitive to the normative pressure of being portrayed as 'laggards' and being 'backward'.

These tactics and strategies form additions to Van de Poel's transformation perspective. They show that his basic transformation mechanisms do not mechanically result in regime transformation, but require enactment. Regime regulations, cognitions and behavioural norms do not change at once, but gradually as insiders and outsiders interact and adjust their activities in ongoing tactical and strategic games.

Although regime transformation is a gradual and stepwise process, it is possible to identify several bigger steps. One big step was the normative change in identity and role perception in the 1890 s, when city governments shifted towards interventionism and more concern for the poorer people in society. This new norm changed investment behaviours that facilitated large-scale sewer implementation. This normative change was facilitated by broader cultural sensitivities about the social issue and by macro-economic growth, which raised tax incomes. Also formal constitutional changes facilitated this change in norms and goals: the widening of the right to vote changed the political rules of the game, creating incentives for politicians to place issues such as hygiene higher on their agenda. But this presupposes that issues such as hygiene are recognised and viewed as important. Hence, cognitive changes must have preceded the normative and political changes. Two crucial cognitive changes in the perception of disease were: (a) medical statistics, which demonstrated correlations between hygienic conditions and infectious disease; (b) Pasteur's micro-organism theory, which articulated underlying causal mechanisms. These considerations point to a general hypothesis: big normative and regulative changes are preceded by important cognitive changes.

The institutional and sociological analysis in this section has focused on the mechanisms, tactics and 
strategies in the enactment of regime transformation. It should be noted, however, that the insider-outsider interactions were influenced by broader developments such as urbanisation, industrialisation, macro-economic growth, democratisation, cultural sensitivity to the social issue, the ideology of cleanliness, societal respect for engineers. These broader developments influenced the playing field, and also provided resources for actors, e.g. through tactics such as issue linkage.

\section{Conclusions}

Most conceptualisations of transitions emphasise the process of technological substitution. Building on Van de Poel, this article proposed regime transformation as another transition path and elaborated basic mechanisms. This process is enacted by regime insiders, in response to pressures from outsiders. As regime actors gradually change regulations, behavioural norms and cognitions, development trajectories are reoriented in new directions. Over time, this may culminate in substantial system changes. The case study demonstrated that the hygienic transition to sewer systems followed this transformation path. Further analysis of the case study resulted in additions to the transformation perspective, particularly with regard to strategies and tactics employed by regime insiders and outsiders. The scope of these conclusions is wider than the single case study, because both the general transformation mechanisms and the tactical and strategic games were formulated in theoretical terms, and do not only rely on empirical illustrations. The analysis also specified a general hypothesis for further research: cognitive changes and learning processes precede big normative and regulative changes.

\section{Acknowledgements}

I want to thank three anonymous referees for their useful comments on previous versions of this paper. I also gratefully acknowledge financial support from the Dutch Knowledge Network on System Innovation (KSI).

\section{References}

Bijker, W.E., 1995. Of Bicycles, Bakelites and Bulbs: Towards a Theory of Sociotechnical Change. The MIT Press, Cambridge, MA, London, England.

Brown, J.C., 1988. Coping with crisis? The diffusion of waterworks in late nineteenth-century German towns. The Journal of Economic History 48 (2), 307-318.

Buiter, H., 2005. Riool, Rails en Asfalt. 80 Jaar Straatrumoer in Vier Nederlandse Steden. Walburg Pers, Zutphen.
Cain, L.P., 1978. Sanitation Strategy for a Lakefront Metropolis: The Case of Chicago. Northern Illinois University Press, De Kalb.

Daru, M., 1985. De Kwestie der Faecaliën. Erasmus University Rotterdam.

Daru, M., Van Zon, H., 1987. Afval en milieu in de negentiende eeuw. De Ingenieur 99 (5), 55-61.

Elzen, B., Geels, F.W., Green, K. (Eds.), 2004. System Innovation and the Transition to Sustainability: Theory, Evidence and Policy. Edward Elgar, Cheltenham.

Evans, R.J., 1987. Death in Hamburg: Society and Politics in the Cholera Years, 1830-1910. Clarendon Press, Oxford.

Freeman, C., Perez, C., 1988. Structural crisis of adjustment, business cycles and investment behaviour. In: Dosi, G., Freeman, C., Nelson, R., Silverberg, G., Soete, L. (Eds.), Technical Change and Economic Theory. Pinter, London, pp. 38-66.

Geels, F.W., 2002. Technological transitions as evolutionary reconfiguration processes: a multi-level perspective and a case-study. Research Policy 31 (8-9), 1257-1274.

Geels, F.W., 2004. From sectoral systems of innovation to sociotechnical systems: insights about dynamics and change from sociology and institutional theory. Research Policy 33 (6-7), 897-920.

Geels, F.W., 2005a. Technological Transitions and System Innovations: A Co-Evolutionary and Socio-Technical Analysis. Edward Elgar, Cheltenham.

Geels, F.W., 2005b. Co-evolution of technology and society: the multilevel perspective and a case study, the transition in water supply and personal hygiene in the Netherlands (1850-1930). Technology in Society 27 (3), 363-397.

Geels, F.W., Schot, J.W. Taxonomy of sociotechnical transition pathways. Research Policy, submitted for publication.

Hamlin, C., 1992. Edwin Chadwick and the engineers, 1842-1854: systems and anti-systems in the pipe-and-brick sewers war. Technology and Culture 33 (4), 680-709.

Houwaart, E., 1991. De Hygiënisten: Artsen, Staat en Volksgezondheid in Nederland, 1840-1890. Historische Uitgeverij Groningen, Groningen.

Houwaart, E., 1993a. Medische statistiek. In: Lintsen, H.W., et al. (Eds.), Geschiedenis van de Techniek in de Negentiende Eeuw, Deel 3. Walburg Pers, Zutphen, pp. 19-45.

Houwaart, E., 1993b. Professionalisering en staatsvorming. In: Lintsen, H.W., et al. (Eds.), Geschiedenis van de Techniek in de Negentiende Eeuw. Deel 3. Walburg Pers, Zutphen, pp. 81-92.

Kemp, R., Schot, J., Hoogma, R., 1998. Regime shifts to sustainability through processes of niche formation: the approach of strategic niche management. Technology Analysis and Strategic Management 10, 175-196.

Kossman, E.H., 1976. De Lage Landen 1780-1914. Elsevier, Amsterdam, Brussel.

Leonard-Barton, D., 1992. Core capabilities and core rigidities: a paradox in managing new product development. Strategic Management Journal 13, 111-125.

Mackenbach, J.P., 1992. De Veren Van Icarus: Over De Achtergronden van Twee Eeuwen Epidemiologische Transities in Nederland. Bunge, Utrecht.

Malerba, F., Orsenigo, L., 1997. Technological regimes and sectoral patterns of innovative activities. Industrial and Corporate Change $6(1), 83-117$.

Melosi, M.V., 2000. The Sanitary City: Urban Infrastructure in America from Colonial Times to the Present. The Johns Hopkins University Press.

Meulders, C., 1992. The Struggle for Cleanliness: A Socio-Historical Analysis of the Laundry Process. Katholic University of Leuven. 
Mokyr, J., Stein, R., 1997. Science, health and household technology: the effect of the Pasteur revolution on consumer demand. In: Bresnahan, T.F., Gordon, R.J. (Eds.), The Economics of New Goods. The University of Chicago Press, Chicago, pp. 143-200.

Nelson, R.R., Winter, S.G., 1982. An Evolutionary Theory of Economic Change. Belknap Press, Cambridge (Mass.).

Reid, D., 1991. Paris Sewers and Sewermen: Realities and Representations. Harvard University Press, London.

Rip, A., Kemp, R., 1998. Technological change. In: Rayner, S., Malone, E.L. (Eds.), Human Choice and Climate Change, vol. 2. Battelle Press, Columbus, OH, pp. 327-399.

Scott, W.R., 1995. Institutions and Organizations. Sage Publications, Thousand Oaks, CA.

Smith, A., Stirling, A., Berkhout, F., 2005. The governance of sustainable socio-technical transitions. Research Policy 34, 14911510.

Tarr, J.A., 1979. The separate vs. combined sewer problem: a case study in urban technology design choice. Journal of Urban History 5 (3), 308-339.

Tarr, J.A., McCurley III, J., McMichael, F.C., Yosie, T., 1984. Water and wastes: a retrospective assessment of wastewater technology in the United States, 1800-1932. Technology and Culture 25, 226-263.

Tarr, J.A., 1988. Sewerage and the development of the networked city in the United States, 1850-1930. In: Tarr, J.A., Dupuy, G. (Eds.), Technology and the Rise of the Networked City in Europe and America. Temple University Press, Philadelphia, pp. 159_ 185.

Tushman, M., Anderson, P., 1986. Technological discontinuities and organization environments. Administrative Science Quarterly 31, $465-493$
Van den Akker, J., 1952. Rioleringen, Deel I: Het ontwerpen en berekenen van een riolennet, Leiden. A.W. Slijthoff's Uitgeversmaatschappij.

Van den Noort, J., 1990. Pion of Pionier: Rotterdam-Gemeentelijke Bedrijvigheid in de Negentiende Eeuw. Stichting PK, Rotterdam.

Van de Poel, I., 2000. On the role of outsiders in technical development. Technology Analysis \& Strategic Management 12 (3), 383-397.

Van de Poel, I., 2003. The transformation of technological regimes. Research Policy 32, 49-68.

Van Driel, H., Schot, J., 2005. Radical innovation as a multi-level process: introducing floating grain elevators in the port of Rotterdam. Technology and Culture 46 (1), 51-76.

Van Zon, H., 1986. Een Zeer Onfrisse Geschiedenis: Studies over NietIndustriële Vervuiling in Nederland, 1850-1920. Rijksuniversiteit Groningen.

Van Zon, H., 1993. Openbare hygiëne. In: Lintsen, H.W., et al. (Eds.), Geschiedenis van de Techniek in de Negentiende Eeuw, Deel 3. Walburg Pers, Zutphen, pp. 47-79.

Verdoorn, J.A., 1965. Volksgezondheid en Sociale Ontwikkeling: Beschouwingen over het Gezondheidswezen te Amsterdam in de $19^{\mathrm{e}}$ Eeuw. Aula, Utrecht.

Walker, W., 2000. Entrapment in large technology systems: institutional commitments and power relations. Research Policy 29, 833-846.

Werkman, E., 1982. Juffer Heb Je een Emmertje Poep: Een Eeuw Amsterdams Rioolwater. Hoofdafdeling Riolering en waterbeheersing Openbare Werken, Amsterdam.

Williams, R., Edge, D., 1996. The social shaping of technology. Research Policy 25 (6), 865-899.

Wohl, A.S., 1983. Endangered Lives: Public Health in Victorian Britain. Dent, London. 